\title{
Knowledge, Attitude and Practices among Pupils towards Hand Washing in Basic Schools-Ombadda Locality-Khartoum State
}

\author{
Ahmed Mohammed Hussein ${ }^{1, *}$, Ahmed Salih², Salma Adam ${ }^{3}$, Ashraf Khattab ${ }^{4}$ and Abdelabasit Burma ${ }^{5}$ \\ ${ }^{1}$ Faculty of Public Heath, Shendi University, Sudan \\ ${ }^{2}$ Faculty of Health Science, Saudi Electronic University and Faculty of Public Health, Shendi University, Sudan \\ ${ }^{3}$ Public Health, Health Education, Ministry of Health Sudan, Sudan \\ ${ }^{4}$ Faculty of Public and Environmental Health, Health Education Department, Khartuom University, Sudan \\ ${ }^{5}$ American Refugee Committee ARC H\&N Manger, Sudan
}

*Corresponding authors: Hussein AM, Faculty of Public Heath, Shendi University, Sudan, E-mail: ahmedalhussein95@yahoo.com

Received: 16 Mar, 2021 | Accepted: 28 Apr, 2021 | Published: 10 May, 2021

Citation: Hussein AM, Salih A, Adam S, Khattab A, Burma A (2021) Knowledge, Attitude and Practices among Pupils towards Hand Washing in Basic Schools-Ombadda Locality-Khartoum State. J Epidemiol Public Health Rev 6(2): dx.doi.org/10.16966/2471-8211.213

Copyright: () 2021 Hussein AM, et al. This is an open-access article distributed under the terms of the Creative Commons Attribution License, which permits unrestricted use, distribution, and reproduction in any medium, provided the original author and source are credited.

\begin{abstract}
Proper hand washing technique is very easy to learn and can significantly reduce the infectious diseases among children. This descriptive crosssectional school-based study was conducted in Ombadda locality Khartoum State Sudan, with an objective to study the knowledge, attitude and practices among basic schools pupils towards hand washing. A sample size of 400 pupils was determined using statistical formula, data were collected using interview and observation, and a pre-prepared and pre-tested questionnaire, and data were analyzed using SPSS. The majority of the pupils $95 \%$ knew the proper way of hand washing with soap and water, $96 \%$ knew the appropriate times for hand washing, sixty five percent of the pupils knew the benefits of hand washing and $88.2 \%$ knew diseases related to the practice of not washing hands. The twenty five percent of the pupil's information about hand washing is from family members, $94.8 \%$ had positive attitude towards hand washing with soap and water, $70.3 \%$ of the pupils practice hand washing with soap and water at appropriate times, $39.5 \%$ practice hand washing in time ranged.
\end{abstract}

Keywords: Knowledge attitude and practices study; Hand washing; Basic schools; Khartoum

\section{Introduction}

Hand washing is defined the process of cleansing the hands with water and soap, for the objectives of removing soil, dirt and microorganisms. The main medical purpose of washing hands is to cleanse the hands of pathogens (including bacteria or viruses) and chemicals, which can cause personal harm or diseases [1]. In the 1980's, food-borne outbreaks and healthcare-associated infections led the Centers for Disease Control and Prevention to more actively promote hand hygiene as an important way to prevent the spread of infection. The outbreak of swine flu in 2009 led to increased awareness in many countries of the importance of washing hands with soap to protect the community from such infectious diseases [1]. Hand hygiene is a way of cleaning one's hands that substantially reduces potential pathogens (harmful microorganisms) on the hands. Hand hygiene is considered a primary measure for reducing the risk of transmitting infection among patients and health care personnel. Hand hygiene procedures include the use of alcohol-based hand rubs (containing 60\%-95\% alcohol) and hand washing with soap and water [2]. Practicing hand hygiene is a simple yet effective way to prevent infections. Cleaning your hands can prevent the spread of germs, including those that are resistant to antibiotics and are becoming difficult, if not impossible, to treat. On average, healthcare providers clean their hands less than half of the time they should. On any given day, about one in 31 hospital patients has at least one healthcare-associated infection [3]. Proper hand washing is the most effective and easiest method to prevent many diseases, but there are many people that do not practice it correctly. The worldwide global hand washing day campaign, which targets school, children as agents for behavior change evidence this problem [4]. Washing hands can keep you healthy and prevent the spread of respiratory and diarrheal infections from one person to the next. Germs can spread from other people or surfaces when you touch your eyes, nose, and mouth with unwashed hands, prepare or eat food and drinks with unwashed hands, touch a contaminated surface or objects [4], blow your nose, cough, or sneeze into hands and then touch other people's hands or common objects. The soaps remove lipid and adhering dirt, soil and various organic substances from the hands, which are detergent-based products that contain esterifies fatty acids and sodium or potassium hydroxide. They are available in various forms including bar soap, tissue, leaf and liquid preparations. Their cleansing activity can be attributed to their detergent properties [5]. An antimicrobial substance which decreases or inhibits the growth of germs in living tissues, examples include alcohols, chlorhexidine gluconate, chlorine derivatives, iodine, chloroxylenol quaternary 
ammonium compounds, and triclosan [6]. Hand hygiene is critical to prevent healthcare-associated infections and reduce the spread of antimicrobial resistance. Compliance with hand hygiene practices has improved over the past two decades, especially in hospitals and healthcare settings where the multi-modal promotion has been implemented [7]. Some diseases spread when hands are contaminated with other moist body substances. Microorganisms transmitted by one or more body substances include Cytomegalovirus, Salmonella typhi, Staphylococcal organisms, and Epstein Barr virus. These organisms maybe transmitted from person to person or indirectly by contamination of food or inanimate objects such as toys [8]. In 2011, the WHO conducted a study in Angola and Ethiopia, to evaluate the Knowledge, Attitudes, and Practices (KAPs) of hygiene among rural school children and assessed the extent to which proper knowledge of hygiene was associated with personal hygiene characteristics. Study included 669 pupils who were interviewed by trained staff participants who were in grades 1-6 at Angola primary's School, located in rural Ethiopia. Data consisted of hygiene and hand washing practices, knowledge about sanitation, personal hygiene, characteristics and presence of gastrointestinal parasitic infection showed approximately $52 \%$ of pupils were classified as having adequate knowledge of proper hygiene, most pupils reported hand washing before meals (99.0\%), but only $36.2 \%$ reported using soap. Although $76.7 \%$ of pupils reported that washing hands after using toilet was important. Only $14.8 \%$ reported actually following this practice. Pupils with adequate knowledge of proper hygiene were more likely to have clean clothes and concluded school based hygiene education is vital in order to decrease the rates of transmissible diseases. Children are more receptive to learning and are very likely to adopt healthy behaviors at a younger age. They can also be agents of change by spreading what they have learned in school to their family and community members [9]. This study conducted in Addis Ababa-Ethiopia to assess knowledge attitude and practice of hand washing and associated factors among primary school. The result found the attitude of students, 142(59.4\%) and 97(40.6\%) have good and poor attitude respectively. Overall 172(71.97\%) of students have a good practice and $67(28.03 \%)$ have poor practice towards hand washing. The study subjects have adequate knowledge and more than half of them have a positive attitude. The overall practice of hand washing is good but utilization of soap and hand washing after toilet visit is low. Educational status, area of residence age six, and grade of student are factors that affect the KAP of school children toward hand washing with soap [10]. A cross-sectional quantitative study was conducted among primary school children in the peripheral site of Karari locality, Omdurman city, Khartoum state, Sudan to assess personal hygiene practices among school children. The study showed that the boys showed better hand hygiene practices before eating rather than the girls $(39.3 \% \& 37.6 \%)$, respectively [11]. A crosssectional, school study was conducted located in Mafraq Governorate, Jordan, over a period of 3 months (October-December 2016). The participants were school students from grades 1 to 12 , randomly chosen from 14 public schools ( 7 girls' schools, 7 boys' schools), the findings showed that the majority of the students (97.5\%) washed their hands with water, and nearly $70 \%$ of them used soap. Furthermore, the majority washed their hands after using the toilet (86.7\%) and after touching rubbish (84.4\%). Reasons for not washing their hands from the students' perspective included, 'no need' $(70.8 \%)$ and 'the hand washing facilities were not clean' (62.3\%). The findings revealed that a low percentage of school students ignored hand washing after different critical situations [11]. A study conducted at Alkalakla basic schools in Sudan, (41.8\%)of the pupils mentioned source of information about hand washing acquiring from school, and (30.8\%) of them mentioned family members are sources of knowledge [12]. The study was conducted in six primary and secondary schools and in the homes of four ethnic villages in northern Vietnam. The study found percentage of students who washed their hands at recommended times (30-60 sec) was $58 \%$. This proportion increased by grade (from $34 \%$ among grade 1 to $67 \%$ among grade 7 ; $\mathrm{p}<0.05$ ) [13].

\section{Material and Methods}

\section{The study design}

This is a descriptive cross sectional school based study to study the knowledge, attitude and practices among basic schools pupils towards hand washing.

Study area: Location: The study area Ombadda locality is located in Omdurman Town in Khartoum.

Study population: The population of the locality (Umbada) is one million about (988.163) people, the study group in this study are pupils in basic schools with a total of (4133) pupils (2106 boys, 2027 girls) distributed in 243 public schools (123 boys, 120 girls ) and 149 private schools ( 81 boys, 68 girls).

\section{Sampling}

Sample size of 400 pupils was determined using the equation $n=\frac{N}{1+N(e)^{2}}$, sample distribution in the locality consist four units, three units out of them were selected randomly using random method to obtain Alamir, Albuqea and Alslam. The sample size was distributed proportionally according to the weight among both boys and girls to obtain 204 girls and 196 boys, from each (girls weight=51 and boys weight $=49$ ) in grade (5-8) and then distributed over 12 schools which were selected randomly 6 public, 6 private using lottery and then the sample was distributed over the schools randomly.

\section{Data collection and analysis}

Interview with the general administration of educational affairs information and centre for training and research were performed. Observations established that the main source of water in all schools is from the public supply system and that all schools had access to attached latrines. Attitudes and practices towards hand washing and data was analyzed using Statistical Package for Social Sciences (SPSS) version 20. The association between different variable was checked using Chi-square test at a 95\% confidence interval, or $\mathrm{p}=0.05$.

\section{Results}

Table 1 revealed that $(61.3 \%)$ of pupils defined hand washing as hands cleaning with water and soap, only $4.5 \%$ the do not have acknowledge regarding to hand washing with soap and water.

Figure 1 shows that $96 \%$ of the pupils have acknowledged the appropriate times for hand washing with soap and water.

The study shows that (65\%) of the pupils knew benefits of hand washing (Table 2).

Table 3 explained that (38.2\%) of the pupils mentioned all types of diseases related to not washing hands.

The study explained that (71.3\%) of pupils who knew the appropriate time for hand washing mentioned all options (Table 4).

Table 5 shows a significant relationship between pupils grade and their source of information about hand washing $\mathrm{P}$ value $=(0.000)$.

The (Table 6) showed that there was not significant relationship between age of pupils and their knowledge about the proper way of hand washing with soap and water $\mathrm{P}$ value $=15.1$. 
Table 1: Demonstrate definition of hand washing as mentioned by the pupils Ombadda locality-2017, N=400.

\begin{tabular}{|l|c|c|}
\hline \multicolumn{1}{|c|}{ Definition } & No & $\%$ \\
\hline Hands cleaning with water only & 18 & 4.5 \\
\hline Hands cleaning with water and soap & 245 & 61.3 \\
\hline Hands cleaning with water and disinfectant & 29 & 7.2 \\
\hline All mentioned & 108 & 27 \\
\hline Total & 400 & 100 \\
\hline
\end{tabular}

Table 2: Shows the knowledge among pupils about type of benefits off hand washing-Ombadda locality-2017, $\mathrm{N}=400$.

\begin{tabular}{|l|c|c|}
\hline \multicolumn{1}{c|}{ Type of Benefits } & No & \% \\
\hline Remove dust & 25 & 6.2 \\
\hline Germs Removal & 115 & 28.8 \\
\hline All mentioned & 260 & 65 \\
\hline Total & $\mathbf{4 0 0}$ & $\mathbf{1 0 0}$ \\
\hline
\end{tabular}

Table 3: Illustrates the diseases related to practice of not washing hands as mentioned by the pupils-Ombadda locality-2017, $\mathrm{N}=353$.

\begin{tabular}{|l|c|c|}
\hline \multicolumn{1}{c|}{ Diseases } & No & $\%$ \\
\hline Diarrhea & 115 & 32.6 \\
\hline Pneumonia & 17 & 4.8 \\
\hline Eye diseases & 16 & 4.6 \\
\hline Typhoid & 25 & 7.1 \\
\hline Dysentery & 13 & 3.7 \\
\hline All mentioned & 135 & 38.2 \\
\hline Other & 32 & 9 \\
\hline Total & $\mathbf{3 5 3}$ & $\mathbf{1 0 0}$ \\
\hline
\end{tabular}

Table 4: Demonstrates knowledge of appropriate times for hand washing with soap and water as mentioned by pupils-Ombadda locality-2017, $\mathrm{N}=384$.

\begin{tabular}{|l|c|c|}
\hline \multicolumn{1}{|c|}{ Appropriate times } & No & $\%$ \\
\hline Before eating & 45 & 11.7 \\
\hline After eating & 9 & 2.3 \\
\hline Before preparing food & 20 & 5.2 \\
\hline After using toilet & 6 & 1.7 \\
\hline After contact with dirt & 15 & 3.9 \\
\hline All mentioned & 274 & 71.3 \\
\hline Other & 15 & 3.9 \\
\hline Total & $\mathbf{3 8 4}$ & $\mathbf{1 0 0}$ \\
\hline
\end{tabular}

Table 5: Shows the relationship between the pupils' grade and their source of knowledge about hand washing-Ombadda locality 2017, N=400.

\begin{tabular}{|c|c|c|c|c|c|c|c|c|c|c|}
\hline \multirow{3}{*}{$\begin{array}{l}\text { Source of } \\
\text { information }\end{array}$} & \multicolumn{8}{|c|}{ The pupils grade } & \multirow{2}{*}{\multicolumn{2}{|c|}{ Total }} \\
\hline & \multicolumn{2}{|c|}{$\begin{array}{l}\text { Fifth } \\
\text { grade }\end{array}$} & \multicolumn{2}{|c|}{$\begin{array}{l}\text { Sixth } \\
\text { grade }\end{array}$} & \multicolumn{2}{|c|}{$\begin{array}{l}\text { Seventh } \\
\text { grade }\end{array}$} & \multicolumn{2}{|c|}{$\begin{array}{l}\text { Eighth } \\
\text { grade }\end{array}$} & & \\
\hline & No & $\%$ & No & $\%$ & No & $\%$ & No & $\%$ & No & $\%$ \\
\hline $\begin{array}{l}\text { Academic } \\
\text { curriculum }\end{array}$ & 11 & 9.8 & 17 & 17.7 & 18 & 18.8 & 17 & 17.7 & 63 & 15.8 \\
\hline $\begin{array}{l}\text { Family } \\
\text { members }\end{array}$ & 20 & 17.9 & 33 & 34.4 & 30 & 31.2 & 17 & 17.7 & 100 & 25 \\
\hline Friends & 0 & 0 & 3 & 3.1 & 3 & 3.1 & 2 & 2.1 & 8 & 2 \\
\hline Mass Media & 0 & 0 & 7 & 7.3 & 5 & 5.2 & 5 & 5.2 & 17 & 4.3 \\
\hline $\begin{array}{l}\text { All } \\
\text { mentioned }\end{array}$ & 61 & 54.5 & 28 & 29.2 & 36 & 37.5 & 54 & 56.3 & 179 & 44.7 \\
\hline Other & 20 & 17.8 & 8 & 8.3 & 4 & 4.2 & 1 & 1 & 33 & 8.2 \\
\hline Total & 112 & 100 & 96 & 100 & 96 & 100 & 96 & 100 & 400 & 100 \\
\hline
\end{tabular}

$X^{2}=55.4 ; d f=15 ; P$ value $=0.000$ Highly significant

Table 6: Shows association between age of the pupils and their knowledge about the proper way of hand washing with soap and water-Ombadda Locality-2017, N=400.

\begin{tabular}{|l|c|c|c|c|c|c|}
\hline \multirow{2}{*}{ Age } & \multicolumn{5}{c|}{ Their Knowledge } \\
\hline & \multicolumn{2}{|c|}{ Yes } & \multicolumn{2}{c|}{ No } & \multicolumn{2}{c|}{ Total } \\
\hline $10-12$ & No & $\%$ & No & $\%$ & No & $\%$ \\
\hline $13-15$ & 209 & 55 & 15 & 75 & 224 & 56 \\
\hline More than 15 & 159 & 41.8 & 4 & 20 & 163 & 40.7 \\
\hline Total & 12 & 3.2 & 1 & 5 & 13 & 3.3 \\
\hline
\end{tabular}

$X^{2}=3.78 ; d f=2 ; P$ value=15.1 Not significant

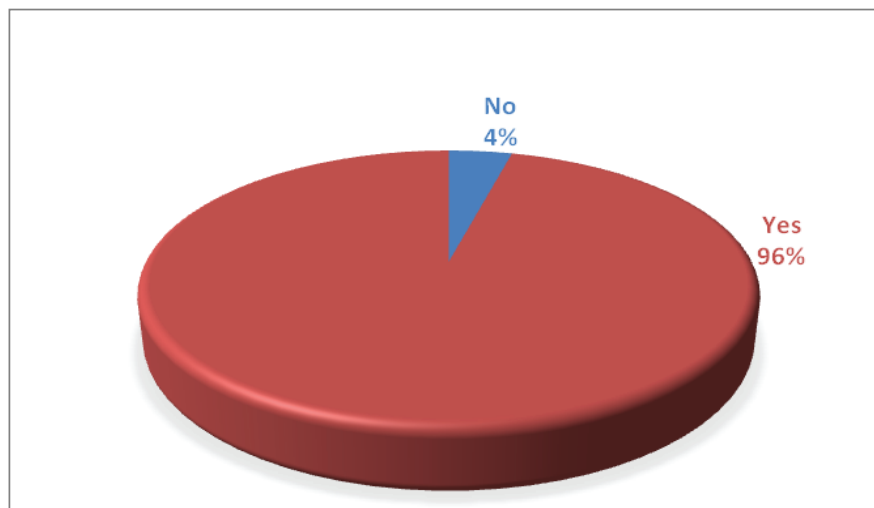

Figure 1: Shows the knowledge among pupils about the appropriate times for hand washing with soap and water-Ombadda locality-2017, N=400. 


\section{Discussions}

The study shows $(61.3 \%)$ of pupils have defined hand washing as hands cleaning with water and soap. Only $4.5 \%$ do not have to acknowledge regarding hand washing with soap and water. This study agrees with, UNICEF [1], CDC [2], and Elmadani M, et al. [10]. Increase awareness in many countries of the importance of washing hands with soap to protect the community from such infectious diseases.

The study demonstrates that (65\%) of the pupils knew the benefits of hand washing this agrees with what mentioned by UNICEF [1]. Washing hands can keep you healthy and prevent the spread of respiratory and diarrheal infections from one person to the next.

The study explained that (38.2\%) of the pupils mentioned all types of diseases related to not washing hands; this agrees with Shrestha A, et al. [8]. Some diseases spread when hands are contaminated with other moist body substances, microorganisms transmitted by one or more body substances include Cytomegalovirus, Salmonella typhi, Staphylococcal organisms, and Epstein Barr virus.

The study shows the study that (71.3\%) of pupils who knew the appropriate time for hand washing mentioned all correct times for washing, this agrees with Bashtawy MAL [11]. The majority of students washed their hands after using the toilet $(86.7 \%)$ and after touching rubbish (84.4\%). This result complies with that stated by Buda AS, et al., [9] who mentioned that (most of the pupils (69.9\%) knew hand washing.

The study showed that most of the pupils (61.3\%) define hand washing, as hands cleaning with water and soap. This result agreed with UNICEF [1] which stated that hand washing is the act of cleansing the hands using water and soap. A small group of pupils (15.8\%) mentioned that their source of information about hand washing is from the academic curriculum and a group of the pupils (4.2\%) mentioned mass media. This result is similar to what was said by Babeker MA [12] (less than half of the pupils (41.8\%) mentioned source of information about hand washing was the curriculum and a group of the pupils (30.8\%) mentioned mass media).

The study shows a group of the pupils (39.5\%) practiced hand washing with soap and water in time ranged between (20-30) seconds. This result complied with Xuan LTT, et al., [13] they indicated that more than half of the pupils (58\%) washed their hands in time ranged between (20-30 seconds).

The study demonstrates the pupils (63.1\%) not washing hands with soap and water at school, this result agree with Babeker MA [12] (the majority of the pupils (82.3)\% didn't practice hand washing at school).

\section{Conclusions}

The study explained that (71.3\%) of pupils knew the appropriate length of time for hand washing. The study also shows that knowledge about the proper way of hand washing with soap and water increase with age. The majority of the pupils (88.2\%) knew diseases were related to the practice of not washing hand with soap.

\section{Recommendations}

1. $1.7 \%$ of student mentioned practices hand washing after using the toilet. This is a very a small number. So increase in student awareness of the practicing washing hand after using the toilet is very important.

2. $15.8 \%$ of students mentioned the sources their knowledge for practices washing hands is schools, this percentage very small. So I recommend increasing the school's health education programs.
Promote the positive attitude towards hand washing and change a negative attitude towards hand washing by the improved correct attitude about hand washing.

Must change a negative behavior like not practicing the proper way of hand washing at critical times, especially before eating and after using the toilet and saving hand washing facilities (water, soap, hand basin) in schools.

\section{Ethical Clearance}

Ethical permission for the study was obtained prior data implementation, by consulting and receiving approval from, Khartoum University, ministry of health, local health authority's, Community Leaders, and consent those who are interviewed.

\section{Acknowledgement}

Authors wish to deeply thank all regional and local health authorities in Ombada locality Omdurman and Ministry of health to support me also thank my colleague and everybody who supported me in completing this project.

\section{University of Khartoum Graduate College}

Medical and Health Studies Board Questionnaire on knowledge, attitudes and practices among pupils toward hand washing in basic Schools Ombadda Locality Khartoum State.

\begin{tabular}{|c|c|c|}
\hline \multicolumn{3}{|c|}{ First: Section of general information } \\
\hline & Gender & $\begin{array}{ll}\text { 1. } & \text { Male [ ] } \\
\text { 2. } & \text { Female [ ] }\end{array}$ \\
\hline & Age & $\begin{array}{ll}\text { 1. } & 10-12[\text { ] } \\
\text { 2. } & 13-15[\text { ] } \\
\text { 3. } & \text { More than } 15[]\end{array}$ \\
\hline 3. & The grads level & $\begin{array}{ll}\text { 1. } & \text { Fifth [ ] } \\
\text { 2. } & \text { Sixth [ ] } \\
\text { 3. } & \text { Seventh [ ] } \\
\text { 4. } & \text { Eighth [ ] }\end{array}$ \\
\hline 4. & $\begin{array}{l}\text { The education level of the } \\
\text { mother }\end{array}$ & $\begin{array}{ll}\text { 1. } & \text { Illiterate [ ] } \\
\text { 2. } & \text { Khalwa [ ] } \\
\text { 3. } & \text { Basic [ ] } \\
\text { 4. } & \text { Intermediate [ ] } \\
\text { 5. } & \text { Secondary [ ] } \\
\text { 6. } & \text { University [ ] } \\
\text { 7. } & \text { Postgraduate [ ] }\end{array}$ \\
\hline 5. & $\begin{array}{l}\text { The education level of the } \\
\text { father }\end{array}$ & $\begin{array}{ll}\text { 1. } & \text { Illiterate [ ] } \\
\text { 2. } & \text { Khalwa [ ] } \\
\text { 3. } & \text { Basic [ ] } \\
\text { 4. } & \text { Intermediate [ ] } \\
\text { 5. } & \text { Secondary [ ] } \\
\text { 6. } & \text { University [ ] } \\
\text { 7. } & \text { Postgraduate [ ] }\end{array}$ \\
\hline 6. & $\begin{array}{l}\text { The family monthly income } \\
\text { by SDG }\end{array}$ & $\begin{array}{ll}\text { 1. } & \text { Less than 450 [ ] } \\
\text { 2. } & 450-1000[\text { ] } \\
\text { 3. } & 1001-1550[\text { ] } \\
\text { 4. } & \text { More than 1550 [ ] }\end{array}$ \\
\hline \multicolumn{3}{|c|}{ Second: Section of Knowledge } \\
\hline & Do you know hand washing? & $\begin{array}{ll}\text { 1. } & \text { Yes [ ] } \\
\text { 2. } & \text { No [ ] }\end{array}$ \\
\hline
\end{tabular}




\begin{tabular}{|c|c|c|}
\hline 8. & $\begin{array}{l}\text { If the answer is yes in question } \\
\text { number ( } 7), \text { what is the hand } \\
\text { washing? }\end{array}$ & $\begin{array}{l}\text { 1. Hands cleaning with water } \\
\text { only [] } \\
\text { 2. Hands cleaning with water } \\
\text { and soap [] } \\
\text { 3. Hands cleaning with water } \\
\text { and disinfectant [ ] } \\
\text { 4. All mentioned [ ] } \\
\text { 5. Other [ ] } \\
\text { 6. Specify [ ] }\end{array}$ \\
\hline 9. & $\begin{array}{l}\text { Do you know benefits of the } \\
\text { hand washing? }\end{array}$ & $\begin{array}{ll}\text { 1. } & \text { Yes [ ] } \\
\text { 2. } & \text { No [ ] }\end{array}$ \\
\hline 10. & $\begin{array}{l}\text { If the answer is yes in question } \\
\text { number (9), what are the } \\
\text { benefits of the hand washing? }\end{array}$ & $\begin{array}{ll}\text { 1. } & \text { Remove dust [ ] } \\
\text { 2. } & \text { Remove germs [ ] } \\
\text { 3. } & \text { All mentioned [ ] } \\
\text { 4. } & \text { Others [ ] } \\
\text { 5. } & \text { Specify [ ] }\end{array}$ \\
\hline 11. & $\begin{array}{l}\text { If you of not washing your } \\
\text { hands with soap this can lead } \\
\text { to diseases? }\end{array}$ & $\begin{array}{ll}\text { 1. } & \text { Yes [ ] } \\
\text { 2. } & \text { No [ ] }\end{array}$ \\
\hline 12. & $\begin{array}{l}\text { If the answer is yes in question } \\
\text { number (11) what are the } \\
\text { diseases that related to hand } \\
\text { washing? }\end{array}$ & $\begin{array}{ll}\text { 1. } & \text { Diarrhea [ ] } \\
\text { 2. } & \text { Pneumonia [ ] } \\
\text { 3. } & \text { Eye Diseases [ ] } \\
\text { 4. } & \text { Dysentery [ ] } \\
\text { 5. } & \text { Typhoid [ ] } \\
\text { 6. } & \text { All mentioned [ ] } \\
\text { 7. } & \text { Others [ ] } \\
\text { 8. } & \text { Specify [ ] }\end{array}$ \\
\hline 13. & $\begin{array}{l}\text { Do you know the right steps } \\
\text { for hand wash with soap and } \\
\text { water? }\end{array}$ & $\begin{array}{l}\text { 1. } \quad \text { Yes }[] \\
\text { 2. } \\
\text { No }[]\end{array}$ \\
\hline 14. & $\begin{array}{l}\text { If the answer is yes in question } \\
\text { number (13) what are the } \\
\text { right steps for hand washing? }\end{array}$ & $\begin{array}{l}\text { 1. Hands moisturizing with } \\
\text { water [ ] } \\
\text { 2. Adding soap for hands [ ] } \\
\text { 3. Massage the interior \& } \\
\text { exterior of hands with soap } \\
\text { and water [ ] } \\
\text { 4. Message fingers and in- } \\
\text { between fingers [ ] } \\
\text { 5. Message thump and hands } \\
\text { wrists [ ] } \\
\text { 6. Dray hands with towels [ ] } \\
\text { 7. Close the tap correctly and } \\
\text { healthy [ ] } \\
\text { 8. All mentioned [ ] }\end{array}$ \\
\hline & $\begin{array}{l}\text { Do you k now the appropriate } \\
\text { times for hand washing? }\end{array}$ & $\begin{array}{ll}\text { 1. } & \text { Yes [ ] } \\
\text { 2. } & \text { No [ ] }\end{array}$ \\
\hline & $\begin{array}{l}\text { If the answer is yes in question } \\
\text { number (15), what are the } \\
\text { appropriate times for hand } \\
\text { washing? }\end{array}$ & $\begin{array}{ll}\text { 1. } & \text { Before eating [ ] } \\
\text { 2. } & \text { After eating [ ] } \\
\text { 3. } & \text { Before preparing food [ ] } \\
\text { 4. } & \text { After using toilet [ ] } \\
\text { 5. } & \text { After contact with dirt [ ] } \\
\text { 6. } & \text { All mentioned [ ] } \\
\text { 7. } & \text { Others [ ] } \\
\text { 8. } & \text { Specify [ ] }\end{array}$ \\
\hline
\end{tabular}

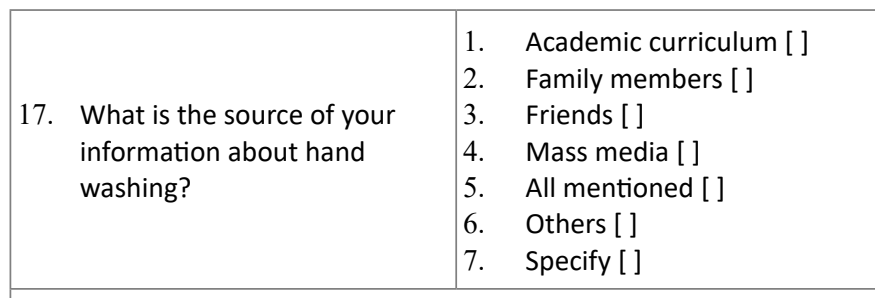

\section{Thirdly: Section of Attitudes}

18. What is your attitude towards hand washing with soap and water?

\begin{tabular}{|l|l}
\hline & Remove dust [ ] \\
2. & Prevent disease [ ]
\end{tabular}

19. If the answer to question (18) 2. Prevent diseases [ is positive, explain why?

4. Other [ ]

5. Specify []

1. Soap causes allergy [ ]

2. Water only enough [

20. If the answer to question (19) 3 . Soap is not available [ ] was negative, explain why? $\quad 4 . \quad$ All mentioned [ ]

5. Other []

6. Specify []

21. If the answer to question (18) is positive, what is your $1 . \quad$ Positive [ ] attitude towards hand washing 2. Negative [ ] after using toilet?

\begin{tabular}{|c|c|}
\hline $\begin{array}{l}\text { 22. If the answer to question (21) } \\
\text { is positive, explain why? }\end{array}$ & $\begin{array}{ll}\text { 1. } & \text { Remove microbes [ ] } \\
\text { 2. } & \text { Prevent disease [ ] } \\
\text { 3. } & \text { All mentioned [ ] } \\
\text { 4. } & \text { Other [ ] } \\
\text { 5. } & \text { specify [ ] }\end{array}$ \\
\hline
\end{tabular}

23. If the answer to question (18) is positive what is your attitude towards hand 1. Positive [] washing with soap and water 2. Negative [ ] before eating?

\begin{tabular}{|c|c|c|}
\hline & $\begin{array}{l}\text { If the answer to question (23) } \\
\text { is positive, explain why? }\end{array}$ & $\begin{array}{ll}\text { 1. } & \text { Remove germs and dirt [ ] } \\
\text { 2. } & \text { Prevent disease [ ] } \\
\text { 3. } & \text { All mentioned [ ] } \\
\text { 4. } & \text { Other [ ] } \\
\text { 5. } & \text { Specify [ ] }\end{array}$ \\
\hline
\end{tabular}

Fourth: Section of behavior

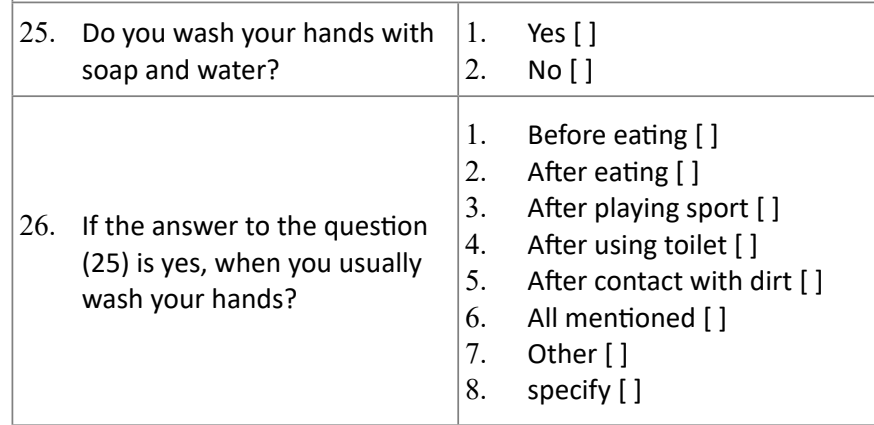




\begin{tabular}{|c|c|c|}
\hline & $\begin{array}{l}\text { If the answer to the question } \\
(25) \text { is yes, how usually does } \\
\text { it take of time to wash your } \\
\text { hands? }\end{array}$ & $\begin{array}{ll}\text { 1. } & \text { Less than } 10 \text { seconds [ ] } \\
\text { 2. } & (10-19) \text { seconds [ ] } \\
\text { 3. } & (20-30) \text { seconds [ ] } \\
\text { 4. } & \text { More than } 30 \text { seconds [ ] }\end{array}$ \\
\hline 28. & $\begin{array}{l}\text { If the answer to the question } \\
(25) \text { is yes, do you dry your } \\
\text { hands after washing with soap } \\
\text { and water? }\end{array}$ & $\begin{array}{ll}\text { 1. } & \text { Yes [ ] } \\
\text { 2. } & \text { No [ ] }\end{array}$ \\
\hline 29. & $\begin{array}{l}\text { If the answer to question ( } 28 \text { ) } \\
\text { was yes, how you dry your } \\
\text { hands? }\end{array}$ & $\begin{array}{ll}\text { 1. } & \text { Using tissues [ ] } \\
\text { 2. } & \text { Using clothes [ ] } \\
\text { 3. } & \text { Air drying only [ ] } \\
\text { 4. } & \text { Other [ ] } \\
\text { 5. } & \text { Specify [ ] }\end{array}$ \\
\hline 30. & $\begin{array}{l}\text { If the answer to the question } \\
\text { (25) is yes, do you wash your } \\
\text { hands using soap and water at } \\
\text { school? }\end{array}$ & $\begin{array}{ll}\text { 1. } & \text { Yes [ ] } \\
\text { 2. } & \text { No [ ] }\end{array}$ \\
\hline 31. & $\begin{array}{l}\text { If the answer to question ( } 30 \text { ) } \\
\text { was no, explain why you do } \\
\text { not wash your hands using } \\
\text { soap and water? }\end{array}$ & $\begin{array}{ll}\text { 1. } & \text { No enough time [ ] } \\
\text { 2. } & \text { Lack of water [ ] } \\
\text { 3. } & \text { Lack of washing basin [ ] } \\
\text { 4. } & \text { Lack of soap [ ] } \\
\text { 5. } & \text { All mentioned [ ] } \\
\text { 6. } & \text { Other [ ] }\end{array}$ \\
\hline
\end{tabular}

\section{References}

1. United Nations Children's Fund (2016) Global hand washing day: Hand washing with soap keeps cholera away from you and your family. UNICEF, South Sudan.

2. Centers for Disease Control and Prevention (2019) Hand Hygiene in Healthcare Settings. CDC, USA.

3. Ejemot RI, Ehiri JE, Meremikwu MM, Critchley JA (2015) Hand washing for preventing diarrhoea. Cochrane Database Syst Rev CD004265.
4. Centers for Disease Control and Prevention (2020) When and How to Wash Your Hands. CDC, USA.

5. Columbus Public Health (2009) Teaching Hand Washing In School. Columbus Public Health, Ohio, USA.

6. Freeman DE, Auer JA (2012) Instrument Preparation, Sterilization, and Antiseptics. In: Stick JA, Auer JA (eds) Equine Surgery. $4^{\text {th }}$ Edition, Elsevier/Saunders, USA.

7. Bowen A, Ma H, Ou J, Billhimer W, Long T, et al. (2007) A clusterrandomized controlled trial evaluating the effect of a handwashingpromotion program in Chinese primary schools. Am J Trop Med Hyg 76: 1166-1173.

8. Shrestha A, Angolkar M (2015) Improving hand washing among school children: an educational intervention in South India. Al Ameen J Med Sci 8: 81-85.

9. Buda AS, Mekengo DE, Lodebo TM, Sadore AA, Mekonnen B (2018) Knowledge, attitude and practice on hand washing and associated factors among public primary schools children in Hosanna town, Southern Ethiopia. J Public Health Epidemiol 10: 205-214.

10. Elmadani M, Elamin E, Tamomh AG, Twum P (2021) Assessment of the Personal Hygiene Practices among Primary Schools Children, Sudan: A Cross-Sectional School-Based Study. Public H Open Acc 5: $1-6$.

11. Bashtawy MAL (2017) Assessment of hand-washing habits among school students aged 6-18 years in Jordan. Br J Sch Nurs 12: 30-36.

12. Babeker MA (2016) Evaluated the Knowledge, Attitudes and Practice (KAP) of Primary School pupils. Department of Health Education Faculty of Public and Environmental Health, University of Khartoum, Sudan.

13. Xuan LTT, Hoat LN (2013) Handwashing among schoolchildren in an ethnically diverse population in northern rural Vietnam. Glob Health Action 6: 1-8. 